\title{
Balkanologie
}

Balkanologie Revue d'études pluridisciplinaires

Vol. I, n 2 | 1997

Volume I Numéro 2

\section{Danube Détente}

Romania's Reconciliation With Hungary After 1996

\section{Tom Gallagher}

\section{OpenEdition}

\section{Journals}

Electronic version

URL: http://journals.openedition.org/balkanologie/222

DOI: 10.4000/balkanologie.222

ISSN: 1965-0582

\section{Publisher}

Association française d'études sur les Balkans (Afebalk)

\section{Printed version}

Date of publication: 1 December 1997

ISSN: 1279-7952

\section{Electronic reference}

Tom Gallagher, « Danube Détente », Balkanologie [Online], Vol. I, n² 2 | 1997, Online since 02 June 2008, connection on 17 December 2020. URL : http://journals.openedition.org/balkanologie/222 ; DOI: https://doi.org/10.4000/balkanologie.222

This text was automatically generated on 17 December 2020 .

(c) Tous droits réservés 


\title{
Danube Détente
}

\author{
Romania's Reconciliation With Hungary After 1996
}

\section{Tom Gallagher}

1 The conflicts in former Yugoslavia have cast a dark shadow over the other countries watered by the river Danube as it flows between Vienna and the Black sea. Patterns of trade have been badly disrupted, resulting in huge economic losses that have made the transition from state-led to market economies even more problem-laden. Prospects for the consolidation of fragile democracies inevitably dwindle as a result of the added social hardships as well as the climate of ascendant nationalism. The tendency of neighbouring states to champion different sides in the conflict, on the basis of longstanding diplomatic, cultural, or religious links, has also blighted the prospects of regional co-operation.

2 The terrible nature of events in the former Yugoslavia have obscured a long-running quarrel between Romania and Hungary which strengthened the forces of radical nationalism in both countries during the early 1990s. So bleak were the prospects of reconciliation between two apparently estranged neighbours that the US Defence Secretary, William Perry observed in 1995 that there had been a time when he was concerned about the possibility of an armed conflict between them ${ }^{1}$. But on 16 September 1996, the leaders of the two countries signed a treaty of friendship which it is hoped will inaugurate a period of lasting stability between two historic rivals.

3 This article analyses the changing conditions which have enabled two formerly intractable neighbours to put aside their quarrels and it examines the obstacles that need to be overcome before a process of reconciliation can hope to be consolidated.

\section{The Roots of Rivalry}

4 Romanian-Hungarian rivalry has mainly centred around the position of the 1,6 million Hungarians living in the majority Romanian province of Transylvania which had been part of Hungary until $1918^{2}$. The conflict had disrupted the Warsaw Pact and after 1989 
blighted prospects of co-operation around regional security issues to do with economic recovery and democratisation.

5 A breakthrough in relations between Romania and Hungary occurred against the background of a NATO drive to admit new members as the Atlantic alliance expanded eastwards. The timing of the agreement suggests that the prospect of shedding their isolation and becoming part of an enlarged European security system is a powerfulenough incentive to enable them to bridge important differences between them.

6 Few inter-state quarrels have been as prolonged and bitter as the one between Romania and Hungary. The announcement on 14 August 1996 that a treaty was ready to be signed came after five years of fruitless negotiations and took most observers by surprise. The significance both sides attribute to the treatment of minorities and to guaranteeing the status of the border between the two countries, has long kept them apart ${ }^{3}$. Romania insisted that any treaty contain a clause whereby Hungary ruled out any peaceful revision of the frontier; meanwhile Budapest, while ruling out any forcible border changes, has declined as long as it perceives that the Hungarian minority in Romania suffers from a lack of civil rights ${ }^{4}$.

7 Hungary sees the status and welfare of Hungarian minorities in neighbouring states as a security issue affecting its stability. The largest Hungarian minority is located in the Romanian province of Transylvania where it comprises one-quarter of the population ${ }^{5}$. This province had been part of Hungary until it was awarded to Romania by the Treaty of Trianon in 1920. More frontier revisions, sponsored by outside powers, saw it briefly return to Hungarian control in 1940-1944 before Romania acquired full sovereignty in the aftermath of World War II.

8 Post-communist Romania rejected claims that the Hungarian minority, comprising $7,1 \%$ of the state population (according to the 1992 census) suffered ill-treatment and it did not disguise its anger whenever Hungary has raised the issue internationally at the UN and the Council of Europe. The sense of insecurity felt by two states whose borders changed frequently in the upheavals that convulsed Eastern Europe between 1914 and 1945, has blocked progress on the signing of the treaty.

9 In many ways, the Romanian-Hungarian dispute is the paradigm case of an inter-ethnic dispute in Eastern Europe. Before 1918, the ascendant Hungarians used their key position in the Habsburg empire to try to assimilate ethnic minorities. They pioneered methods that would be adopted by the successor states that sprang from the Habsburg empire, in order to create a single national identity in fragile multi-ethnic polities. Communists in several East European states would of course take Hungarian methods of administrative centralisation and educational uniformity much further in a bid to erode sub-national cultures that were deemed to be an obstacle to the socialisation of citizens along Marxist-Leninist lines. In the 1980s, the minority which bore the brunt of such an assimilation drive was the Hungarians of Transylvania who adopted forms of passive resistance that the ethnic Romanians in that province had resorted to a century before in a bid to defend their language and culture from the inroads of the Magyar state. 
10 At inter-state level, a number of restraining factors have ensured that, at least since 1990, the Romanian-Hungarian dispute centred on Transylvania has been conducted in a forceful but non-violent manner :

1. The fear of alienating Western institutions which both countries are anxious to join out of a common awareness that their respective national interests can best be defended by rapid amalgamation with Euro-Atlantic economic and security organizations.

2. Shared nervousness about the conflict until 1995 raging in parts of ex-Yugoslavia and the potential for a spillover that might cause Romania and Hungary to collide.

3. Awareness that the inter-ethnic quarrel concerning Romania's Hungarian minority is only the most pressing of several ethnic and territorial problems that both countries face: the Romanian state finds it difficult to come to terms with the loss of the province of Bessarabia, seized by the USSR in 1940 and which, in 1991, became the independent state of Moldova; relations with the Ukraine are strained because the new former Soviet state contains former Romanian territory lost at the same time. Meanwhile, Hungarian concerns over the fate of its co-ethnics in Slovakia and Serbia has resulted in periodic tension with these neighbours.

4. Finally, there is the absence of a military threat as both the armed forces of the states in dispute are weak in terms of manpower, training, and equipment. Military co-operation between the armed forces of Romania and Hungary has actually been the main success story in the stalled relations between these states and the co-operation programme with prospective new members called the Partnership for Peace, launched by NATO in 1994, is strengthening these links.

\section{The Dayton Precedent}

11 There is no doubt that the high-level concern of leading Western governments and NATO over the security crisis affecting ex-Yugoslavia and its neighbours has given much-needed impetus to improving bilateral ties between two historically estranged Danubian states. The growing degree of interest in the stability of former communist states bordering ex-Yugoslavia is of recent duration and may only enjoy a limited lifespan. It largely stems from the US-inspired bid to end the conflict in Bosnia which culminated in the Dayton Accord of November 1995. The need to isolate nationalist hardliners in Bosnia and promote moderate forces capable of arranging compromises across the various ethnic divides was at the centre of the strategy identified with Richard Holbrooke, former US assistant secretary of state.

The architects of the Dayton Accord realise that the success or failure of the initiative depends, in part, on efforts to delegitimise conflictual nationalism in South-Eastern Europe as a whole. But previous Western initiatives, limited though they were, do not offer hopeful precedents. Little now remains, for instance, of the Stability Pact, promoted by the French Premier Edouard Balladur in 1994-1995, and designed to reduce inter-state nationality conflicts involving countries hoping to join the EU. It ceased to be a reference-point for preventing nationalist quarrels undermining European security once Balladur's challenge for the French Presidency ended in defeat. His efforts to induce Romania and Hungary to settle their differences before the March 1995 conference launching the Stability Pact, met with failure ${ }^{6}$. 


\section{The Catalyst of NATO Expansion}

13 The Stability Pact foundered because it lacked concrete incentives that would persuade East European states to put longstanding ethnic quarrels behind them. However, when the North Atlantic Ministerial Council announced at the end of 1995 that NATO was prepared to consider applications for full membership from former Warsaw Pact countries, a new situation arose. The prospect of becoming part of an enlarged Western defence umbrella was an attractive one and both Romania and Hungary submitted applications in the spring of 1996. However, from the outset officials from NATO and its leading members insisted that they were not interested in having as new members countries that were in dispute with their neighbours. The poisonous feud between two unfriendly NATO "allies", Greece and Turkey, cast a very long shadow and there was no desire to be burdened by fresh bilateral quarrels bound to diminish the alliance's effectiveness.

The procession of officials from NATO states visiting Romania and Hungary in 1996 were careful not to make statements that apportioned blame for the deadlock over treaty negotiations or to talk up the chances of one candidate at the expense of the other. US Secretary of State, William Perry and Javier Solana, the NATO SecretaryGeneral, on visits to Bucharest in 1995 and 1996 respectively, praised efforts made by Romania in harmonising military standards with NATO. But Perry emphasised that NATO applicants must settle outstanding disputes with neighbours in order to be seriously considered for entry and Secretary-General Solana, on the eve of a visit to Romania in May 1996, urged the government to make more of an effort to strengthen the rights of ethnic minorities ${ }^{7}$. Hitherto, the Romanian government - together with most opposition parties - had seen the treatment of ethnic minorities as a broadly internal matter not to be considered in relations between states.

15 A candidate nation's chances of joining NATO depended on its performance in democratising its society, reforming its economy, settling differences with adjacent states, and restructuring its military in accordance with Western standards. In terms of the stability of its democratic system, its economic progress, and its relations with other countries in the region, Romania's credentials for NATO membership, were weaker than most other applicants. The country's political system displays growing oligarchical tendencies and mounting economic and social difficulties are being faced in what is proving to be a protracted transition from communism. Above all, the failure of bilateral treaty negotiations with the Ukraine and Russia, and the delay in normalising relations with Moldova (much of which had been ruled from Bucharest in the inter-war years), are likely to suggest to wary NATO planners that Romania might be a consumer of security, rather than a provider of it, if it joined while its ties with most neighbours were in such poor repair8.

\section{Hungary Stumbles}

16 The reform process in Hungary is undoubtedly stronger on most civil fronts than in Romania. The Socialist-Liberal coalition government of Gyula Horn, elected in May 1994, managed in 1995 to sign a bilateral treaty with Slovakia where the second largest Hungarian minority is located. The Horn government is seen as far more pragmatic on minority issues than its conservative nationalist predecessors. However, in July 1996 
the palpable sense of complacency in Budapest about the steady progress Hungary was making towards admission to NATO in the first round of expansion, was dashed by adverse Western reaction to a declaration signed by the Hungarian government which contained a certain amount of rhetorical nationalism hitherto associated with the 1990-1993 government of Jozsef Antall.

On 5 July, a summit of Hungary's ethnic minorities issued a declaration, together with the Horn government, in which it was stated that the survival of Hungarian communities outside the state could only be assured by "autonomy" and "selfgovernment". The US State Department reacted on 29 July by saying that it rejected the concept of territorial autonomy on an ethnic basis and that it presumed the Budapest declaration did not represent any change in the Hungarian government's policy. More forthright was Congressman Charles H. Smith, chairman of the US Congress's Helsinki Committee who, on 2 August complained that the participants of the Budapest summit concerned themselves with " ambiguous support for autonomy " and "self-government", knowing that the use of these terms must "induce alarm in countries which are already afraid of alleged irredentism $»^{10}$.

Budapest could not afford to take such criticism lightly. Smith is one of the few Congressional experts on South-Eastern Europe and he has a proven record of impartiality. He had lobbied hard against the US government's decision in June to grant Most Favoured Nation trading status on a permanent basis to Romania on account of what he saw as the continuing influence of neo-communist thinking at the upper levels of government. The Romanian's naturally drew comfort from Budapest's discomfiture President Ion Iliescu declaring that « Hungary and NATO are going to enter NATO together or not at all $»^{11}$. Hitherto Hungary had dismissed such statements as groundless. It had also been unmoved by statements emanating from the Romanian, defence Minister, Gheorghe Tinca, about the security risks that would entail if a new partition line was drawn in a part of Europe already full of volatility ${ }^{12}$.

Whether it realised it or not, the Hungarian government's endorsement of the Budapest declaration gave some external credibility to Romanian fears and thus strengthened the bargaining position of the Bucharest government. Having said in June that it did not see the point in resuming treaty negotiations until after Romanian elections due in November, the Horn government made a volte-face and resumed negotiations on 11 August. Three days later it was announced that the text of a bilateral treaty had been "practically finalised» and that the treaty could be signed in midSeptember ${ }^{13}$.

20 Compromise had been reached over the Council of Europe's Recommendation 1201 on minorities which hitherto Romania had refused (unlike Slovakia) to write into the bilateral treaty with Hungary because of fear that it might be seen as giving formal approval for the idea of political autonomy for minorities. But Bucharest withdrew its objection as long as it was made clear that the joint interpretation of 1201 should neither refer to collective rights, nor force the two sides to grant any autonomy status on ethnic grounds ${ }^{14}$.

21 It is already clear that the prize of being inside the Western military umbrella and the alternative of isolation, concentrated the minds of two intractable neighbours hitherto unable to bridge their differences. The exact role of the West in promoting a settlement remains unclear, but it was far from negligible and the US State Department was active in the weeks before the breakthrough was announced ${ }^{15}$. 


\section{Domestic Agenda Promote A Settlement}

Domestic pressures were also important in closing the gap between the two sides, particularly in the case of Romania. President Iliescu and the ruling party, Partidul Democraţiei Sociale din România (Party of Romanian Social Democracy in Romania, PDSR) were preparing for presidential and parliamentary elections on 3 November 1996. The PDSR had done badly in local elections in June on account of its economic record and persistent allegations of corruption among top officials. The reformist opposition had profited from widespread disenchantment over falling living standards and government mishandling of the economy to take the lead in opinion polls. No electoral contender is plausibly able to offer better economic times for Romanians who face more years of retrenchment before the economy can recover from the colossal policy errors and waste of resources that occurred in the Ceauşescu era. But the President and his supporters feel that successes on the foreign policy front can enable the PDSR to regain the political initiative.

The post-communist regime in Romania has struggled hard to acquire international respectability. The communist background of much of the post-1989 leadership and the controversial methods used to acquire power in 1990 made Romania a pariah state in the eyes of major Western governments until its usefulness in containing the conflict in the former Yugoslavia brought a change of heart in the West. Despite his communist pedigree and residual authoritarianism, President Iliescu was broadly viewed as genuine in wishing to align Romania firmly with the West. The wish to "rejoin Europe" is overwhelmingly popular among Romanians, $95 \%$ in a Eurobarometer poll of March 1996 supporting NATO entry, no other East European state registering such a degree of public enthusiasm ${ }^{16}$. In actively pursuing admission to NATO, securing preferential trading links with the USA, and improving ties with Hungary, the government was broadly in line with public opinion.

Midway through its term, the left-leaning Horn government in Hungary also needed foreign policy successes to compensate for a faltering performance at home. A failure to revive the stagnant Hungarian economy and controversy over the conduct of privatisation schemes has provoked government disunity and a slump in its popularity. The clinching of an agreement with Romania would be the clearest affirmation of Premier Horn's desire for a historic reconciliation with Hungary's neighbours which had proverb such a popular electoral issue for him in 1994. In its preoccupation with minority questions, the Antall government had often appeared more concerned with non-citizens than with its own voters ${ }^{17}$. The conservative government of the Hungarian Democratic Forum (HDF) had over-estimated the concern felt in Hungary for the three million co-ethnics to be found in neighbouring countries by emphasising that Hungary's relations with these states would be largely determined by their record on minority rights. The Antall government endorsed the 1975 Helsinki Final Act and the 1990 Treaty of Paris which ruled out the revision of European frontiers by force while refusing to deny the possibility of peaceful frontier revisions at some future date ${ }^{18}$. Bilateral co-operation with Hungary on defence matters and trade continued against a frosty background in which the two countries scored points against each other at international events and launched initiatives seen as unfriendly by the other side ${ }^{19}$. 
At times, nationalist statements from government officials in Budapest proved distinctly unhelpful for their co-ethnics in Romania. In 1992 the position of the Hungarians in Transylvania was weakened by a statement from the defence minister of Hungary, Janos Für who declared that the safeguarding of Hungarians everywhere is inseparable from the security of his nation and the Hungarian government and parliament should do everything in their power, using all legal and diplomatic means, to end the threat to the minority and to guarantee their survival ${ }^{20}$. This ill-judged statement, coming on the eve of the Romanian local elections, ensured victory in a tightly-fought contest for the hardline nationalist, Gheorghe Funar who, as mayor of the city of Cluj, has directed his fire against the Hungarian minority and done serious damage to inter-ethnic and inter-state relations by virtue of his Partidul UnitaŢii NaŢionale Române (Party of Romanian National Unity, PUNR) being in the ruling coalition from 1994 to $1996^{21}$. It is not the first, nor will it be the last time, that hardliners on opposite sides of an ethnic dispute have rendered this kind of service to one another.

Premier Horn has worked to undo the mistakes of Hungarian foreign policy by disavowing Antall's 1990 statement that he was Prime Minister "in spirit" of 15 million Hungarians, (that is including those in neighbouring states) and by making it clear that he had no lingering attachment towards revising the Trianon settlement even by peaceful means. His economic failures have enabled the opposition parties to promote nationalism but the government in Budapest has freedom to manoeuvre in the way that it approaches the minority question and defines ties with neighbouring states. Irredentist sentiment is weak in Hungary and, thanks to the communist authorities hostility to displays of nationalism, the generations born after 1945 often display little interest in, or awareness of, the situation of the minorities.

\section{The Nationalist Temptation in Romania}

Co-operation between Horn and Iliescu was made easier by the fact that both are excommunists with a reputation as pragmatists within their liberal and despotic pre-1989 authoritarian political systems. As foreign minister during the violent overthrow of the Ceauşescu regime, Horn rendered Iliescu valuable assistance as he sought to gain international recognition. for his de facto Frontul Salvării Nationâle (National Salvation Front, FSN ${ }^{22}$. President Iliescu faced more constraints given the higher profile nationalism enjoys in Romanian political culture : the ruling PDSR had been dependent on the support of ultra-nationalist parties during the lifetime of the Văcăroiu government (1992-1996) and the reformist opposition had become mildly nationalistic in a bid to defeat its rival at the polls ${ }^{23}$. Although the strength of post-communist nationalism in Romania springs from a sense of insecurity, nationalism was also discreetly promoted by Iliescu and his entourage in order to deny to the opposition such a valuable political card.

Iliescu has usually refrained from making crude nationalist statements but he shares one important feature with the chauvinist bloc: he has no interest in replacing a passive political culture in which a low value is placed on participation with an active one in which voters are able to create the autonomous space necessary for genuine pluralism to flourish ${ }^{24}$. The ultra-nationalist parties which the government promoted to eat into the opposition's support in Transylvania, eventually escaped from central 
control and, thanks to their extremism, they did serious damage to Romania's international image during the early 1990s. The government shoved its own latent nationalism by building alliances with parties well-known for their anti-semitism and nostalgia for Ceauşescu's brand of national communism. A protocol was even signed in January 1995 between the ruling PDSR and the Jew-baiting Greater Romania Party, the anti-Hungarian PUNR, and the leftist Socialist Workers Party which placed Romania in the unenviable position of being the only government in eastern Europe dependent on such extremist movements ${ }^{25}$.

The ascendancy of extremist parties which were soon busy inserting supporters in important ministries and sensitive local positions has not helped inter-ethnic relations. But there has been no repeat of the violent clashes between Romanians and Hungarians in the city of Tirgu Mureş during March 1990 which first revealed that nationalist hatreds had not perished with the dictatorship. Indeed, thanks to the patient work of NGOs such as the Pro-Europe League committed to ethnic co-existence, community relations have recovered in a city shared almost equally by the two main ethnic groups $^{26}$. In Transylvania generally, Romanians and Hungarians often are suspicious and at times anxious about the political intentions of leaders from the other community, but there is not usually the hate or permanent distrust that can disfigure everyday life in other zones of majority-minority conflict in the region. The Transylvanian paradox is that several elected officials and government appointees have been stirring up antagonism while relations between Romanians and Hungarians on the ground are virtually free of tension except in the city of cluj and, elsewhere on emotive days of the year. But there is always the danger that local disputes over the use of bilingual signs or the erection of statues to Romanian nationalists, may trigger off unrest that has reverberations at inter-state level between Romania and Hungary.

Romania offered a study in ambiguity between 1992 and 1996: it was committed to integration with European institutions and to replacing the command economy with a hybrid but basically market-led one. However, at the same time the ruling party has made a series of tactical alliances with ultra-nationalists (which would be recognised as appropriate in Serbia) to control what is proving to be a lengthy and, in some ways, qualified transition from national communism. If a sharper boundary had been drawn between the government and ultra-nationalist parties which have never gained more than 12 to 15 per cent of the Romanian vote, it is likely that a state treaty with Hungary could have been signed much earlier than this.

\section{Treaty Pressurises Hungarian Minority}

31 Predictably most extreme nationalists have denounced Iliescu for allegedly selling out to Budapest. But, ultimately, it may be the Hungarian minority which finds the treaty hardest to swallow. Since 1990, Uniunea Democrată Maghiară din România (the Democratic Union of Hungarians in Romania, UDMR) has been the recognised voice of most Hungarian voters. It firmly rejects separatism, knowing that this wildly unrealistic objective finds little favour with Romania's Hungarians most of whom live far from the border with Hungary, much of the territory in between being inhabited overwhelmingly by Romanians. But it demands wide-ranging autonomy which has placed it out on a limb in Romanian politics. 
32 It is not always easy to determine what form of autonomy the UDMR wants as its various pronouncements are open to differing interpretations, which gives its enemies useful ammunition. But this much is clear: the UDMR believes that the interests of Hungarians in Romania can only be properly defended by territorial autonomy for areas in which Hungarians constitute a majority and personal autonomy, with an emphasis on safeguarding cultural identity, in areas where the population is more dispersed ${ }^{27}$. The UDMR's stance was radicalised at its 1995 congress as a result of the Văcăroiu's government growing links with Romanian extremists and following the failure of its electoral alliance with the reformist opposition to bring its goals any nearer ${ }^{28}$.

Compared with most Romanian parties, the UDMR is a professional, well-organized force which practices a high degree of internal democracy and is able to rely on a high turnout of Hungarian voters at elections. The UDMR's current effectiveness may stem from the fact that the Hungarian minority was involved in building a Hungarian state down to 1918. This distinguishes it from most other stateless minorities in the region in opposition to national states.

The 1991 Romanian constitution is opposed by the UDMR because it defines Romania as a national state. The party fears that this could be used as the basis for denying Hungarians a separate cultural identity ${ }^{29}$. One law which provoked strong resistance was the 1995 Education law which is condemned for greatly restricting access to higher education in the Hungarian language. The UDMR fears that this law will encourage the slow motion assimilation of the Hungarian minority by obliging the brightest young people to go abroad for their university education. In 1995, it gathered almost 500000 signatures in less than two months for a petition against the bill. This demonstrated, according to two liberal Romanian analysts, that « the party represented the will of the Hungarian minority in Romania $»^{30}$. But much of Romanian opinion sees the party's mobilising campaign as a potential threat to the territorial sovereignty of the country. The nationalist bloc of parties wants it banned outright while even a well-known liberal commentator like Alina Mungiu suspects that the insistence on cultural autonomy... is a sign that "the Hungarian elite in Romania is preparing for eventual secession", albeit of a peaceful kind more akin to the aims of many French speakers in Quebec than non-Serbs in former Yugoslavia ${ }^{31}$.

The UDMR's model for an enduring ethnic settlement in Romania is the significant autonomy granted to the German-speaking minorities living in Italy's South Tyrol which has been the basis for Austro-Italian reconciliation. The Romanian political elite prefers the model of Franco-German reconciliation which involved an accommodation at state level between two historic rivals and was not based on the redress of minority grievances. Indeed in 1995 President Iliescu proposed that Romania and Hungary followed such a model when negotiations between the two states had become stalled ${ }^{32}$.

The UDMR fears the Franco-German model citing the fate of the Alsatian population which it feels has been subject to assimilation from Paris. However, it was not consulted by the Horn government about the basis of the agreement reached with Romania in August 1996 and the UDMR was rebuffed when it requested a meeting with the Hungarian premier to express its concerns about the absence of any reference to the collective rights the Hungarian minority in the draft of the proposed treaty. But the Horn government can afford to turn a deaf ear to the UDMR as it strives to enhance Hungary's prospects of being within a new European security umbrella : the UDMR only 
possesses moral influence and not electoral clout in Hungarian state politics and it is most unlikely to turn to extremism given its attachment to constitutional politics.

\section{A Peaceful Change of Regime in 1996}

The Romanian-Hungarian treaty meant that the Romanian election campaign, though fiercely fought, was the first one since 1989 that was largely free of nationalist rancour. The two main opposition alliances, Convenţia DemocraŢică Româna (Romanian Democratic Convention, CDR) and Uniunea Social Democrata (Social Democratic Union, USD) won an outright majority in the parliamentary elections of 3 November 1996. They rallied behind the presidential candidacy of Emil Constantinescu who defeated the incumbent on 17 November. Iliescu was rejected because he had reneged on promises of social protection, especially to urban workers, corruption was too omnipresent to conceal from many former supporters, and the Văcăroiu government had become a byword for administrative incompetence ${ }^{33}$. Millions of ex-Iliescu voters had acquired their own agenda for change and were ceasing to be reliant on a paternalistic and flawed leader. The generally-incident free election campaign suggested that Romanian political culture was beginning to outgrow the Balkan stereotype dominated by images of partisanship, collectivist values, and nationalism ${ }^{34}$.

The new President's choice to head the government was Victor Ciorbea, a 42-year-old lawyer from Transylvania who soon showed a strong personal commitment to improving ties with the Hungarian minority. In speeches, diplomatic initiatives, and approaches to the Hungarian minority, Romania's new rulers offered a new definition of patriotism which public opinion responded well to. President Constantinescu made it clear that he saw the chief threats to Romanian national sovereignty as being internal rather than external in origin. He saw the need to abandon the post-communist strategy involving «the political instrumentalization of myths, religious fundamentalism skilfully used for political ends, isolation and other aggressive discourses $»^{35}$.

The political marginalisation of the Hungarian minority ended when two members of the UDMR joined the Christian Democrats (PNTCD), the Liberals, and the Democratic Party (PD) in the government of Victor Ciorbea. A development which would have been seen as novel and shocking only a short time before soon passed without notice and gave rise to no adverse reaction from Romanian society. The image of Romanians and Hungarians as insiders and outsiders locked in a majority-minority power relationship was given a powerful dent. The prospects for inter-ethnic co-operation appeared promising since, joining the two Hungarians in the government, was Gavril Dejeu of the PNTCD, the new minister of the interior. In 1940, he had been orphaned at the age of 8 when his father was killed by occupying Hungarian troops, but he refused to be the prisoner of a tragic history and the determination to bury a divisive past soon became a hallmark of the reformist coalition ${ }^{36}$.

The role of the Romanian state in dealing with ethnic diversity was re-assessed in the first half of 1997; in May the government amended the educational and local administration laws, giving minorities the right to be schooled in their mother tongue at all levels as well as the right to use their language in court and in the local administration. The government had already published plans to introduce bilingual signs in areas of minority settlement and a Hungarian consulate was to be opened in 
Cluj in the summer. These measures produced no public outcry and even the nationalist parties and the PDSR initially found it hard to rouse their supporters to protest in large numbers.

41 The rapprochement between neighbours and historic rivals was marked by a series of high-level visits. Adrian Severin, the new Romanian foreign minister, paid his first official visit abroad to Hungary at the end of 1996. Hungary's backing for Romanian entry into NATO was confirmed and a range of initiatives to strengthen defence and economic co-operation were announced. In his March 1997 visit to Budapest, Premier Ciorbea emphasized the importance of economic and military co-operation. He made it clear that he hoped to benefit from Hungarian investment and its greater experience of market economics in order to relaunch the Romanian economy ${ }^{37}$. This marked a change from the Iliescu era when the government was reluctant to encourage investment from Hungary. Nationalist parties viewed such investment as tantamount to the recolonization of the country and had discouraged it in parts of Transylvania where they enjoyed influence. But when Hungary's President, Arpad Goncz paid a state visit to Romania from 25-27 May 1997, he found that there were 800 companies with mixed capital drawn from both countries operating in the Tirgu Mureș area alone ${ }^{38}$.

Premier Ciorbea shared a strong personal commitment to improving RomanianHungarian ties at the human level. He spoke about his own friendly contacts with Hungarians at school, university and while serving in the army. He established a precedent by sending greetings to Hungarians in Romania celebrating their national day on 15 March and by allowing state officials to participate in the festivities ${ }^{39}$. The significance of the gesture is clear when recalling the historical events in questions.

The Hungarians were commemorating the 1848 revolution led by Louis Kossuth who had refused to recognise the existence of a Romanian nation in Transylvania. Conflicting nationalists neutralised each other's bid for freedom in a territory in revolt against imperial rule. Avram Iancu, the leader of the Romanian $1848^{\text {ers }}$ in Transylvania appealed to the Hungarians «to understand that weapons can never decide between you and us. Fate put us in a homeland so that together we can strive to improve it and enjoy the results $»^{40} .150$ years later, Ciorbea's bid to carry fellow Romanians with him as fences were mended with Hungary and its co-ethnics living in Romania, were strengthened by the fact that he came from Iancu's locality in the Apuseni mountains, still viewed as a cradle of Romanian nationalism.

But foresight and tact are needed in defusing sensitive inter-ethnic issues otherwise the good intended can be lost. If a reminder of this axiom was needed, it was provided in March 1997 when Prime Minister Ciorbea outlined a two-stage process whereby a Hungarian section would be established at Babes-Bolyai university in Cluj followed by the creation of a separate Hungarian language university ${ }^{41}$.

Ciorbea's proposal was condemned outright by the left-nationalist bloc of parties, but it also divided opinion within Cluj's main university. Hitherto, the university had played a moderating role during the nationalist tensions provoked by the city's controversial mayor. But one pro-rector threatened to resign while another backed the right of Hungarians to their own university; Romanian and Hungarian student associations adopted different positions; significantly, the cluj branches of the main parties in government soon expressed their unhappiness about Ciorbea's move ${ }^{42}$. in one of the most sensitive questions in relations between the two Transylvanian 
communities would be vital for success. But little skill was displayed by the government as it took a new initiative in such a sensitive field. Ciorbea took his stand without consulting the university's rector, Andrei Marga whom he would normally consider an ally because of his commitment to human rights and inter-ethnic tolerance. The government may have decided that a process of prior consultation would mobilise a coalition opposed to the Hungarian university. However, its haste and failure to prepare public opinion left the government isolated. A retreat was then announced: after meeting with university leaders President Constantinescu announced that one university would survive but with Romanian and Hungarian sections. Eventually, on 21 October 1997, on the occasion of the Hungarian Prime Minister's visit to Bucharest, the Romanian government expressed its willingness to see a Hungarian language university founded in Transylvania ${ }^{43}$.

The mishandling of the Cluj university question did little damage to the government. Until the summer of 1997 public opinion displayed strong confidence in the ambitious economic strategy intended to relaunch the moribund state-led economy through sweeping privatisation measures and a sharp cut in state subsidies for the politically influential but economically doomed heavy industry sector. Support for Ciorbea's shock-therapy plans, which included the liberalisation of prices for all foodstuffs and energy products was high, despite the adverse affect it was already having on the purchasing power of the average consumer ${ }^{44}$. There was also much hope that the enormous time and effort the new government had invested in promoting Romania's NATO bid would result in Romania being invited to join at the Alliance's Madrid summit on 8-9 July.

But the six months of frenetic reforms were insufficient to make up for the six years "lost" under Iliescu and the PDSR. Hungary's bid to join NATO was accepted but Romania was informed that it would have to re-apply in the next round of expansion. Constantinescu had prepared public opinion for the rebuff in June by warning that the pace of economic reform was proving a hindrance to Romania's admission chances ${ }^{45}$. An opinion poll in late May showed that $29 \%$ of voters blamed the PDSR for any failure of Romania's NATO bid compared with $16 \%$ holding the Ciorbea government responsible ${ }^{46}$. There was little noticeable public anger that Hungary had been selected and Romania spurned.

President Clinton tried to assuage disappointment by paying an 8-hour visit top Bucharest on 11 July where he declared that « the door to NATO is open, will stay open, and we will help you pass through it $»^{47}$. If nothing else, this visit showed that Washington felt it important to provide top-level support to Romania's reformers, perhaps out of a belief that their success could have a stabilising influence in SouthEastern-Europe as a whole.

In retrospect, it appears that Romania's high-profile campaign to join NATO in 1997 was in no small measure connected with the need to preserve unity within a fragile coalition and contain popular discontent about poorly-applied attempts to restructure the economy on a competitive basis. In the weeks following the Madrid summit, it was striking how the Ciorbea government found itself thrown on to the defensive as a result of coalition wrangles, hesitation about applying radical economic measures, and the failure to spearhead a firm anti-corruption campaign which had been one of the promises that had initially boosted its popularity. 


\section{Nationalist Revival}

51 With Iliescu's PDSR in even more disarray, it was the ultra-nationalist parties that were best-placed to exploit the government's difficulties. In the second half of 1997, they were able to exploit inter-ethnic controversies that were relatively minor ones compared with the Cluj university question and the inclusion of Hungarians in the government. In Cluj Mayor Funar won fresh publicity and broke the law by having the Hungarian flag removed from the newly-opened Hungarian consulate in the city ${ }^{48}$. The closure of an orphanage containing mainly Romanian children in the UDMR-controlled town of Odorhei Secuiesc, led to claims that the welfare of the Romanian minority in Hungarian-dominated areas was in jeopardy because of arbitrary UDMR officials ${ }^{49}$. Finally, the decision by some UDMR councils to erect bilingual signs before the relevant law had been passed in parliament, gave rise to ill-feeling in parts of Transylvania which nationalists were able to exploit.

The credibility of the most extreme of the nationalist politicians, Corneliu Vadim Tudor, leader of the Greater Romania Party (PRM) was boosted when the PDSR formed a working alliance with his and other nationalist formations. Indeed Tudor upstaged Iliescu at the PDSR's own conference on 21 June 1997; he was acclaimed by the audience and Iliescu warmly welcomed on to the podium a man who, just a year before, had accused the then Romanian President of being an agent of the KGB ${ }^{50}$.

Iliescu may well come to regret entering into such a Mephistophelian pact. Hitherto he had always claimed to be equidistant between the claims of the UDMR and its Romanian chauvinist opponents. The pact brought the PDSR few rewards ; in Bucharest autumn rallies protesting about government policies were poorly attended. Nationalist issues failed to persuade southerners to take to the streets. But in Transylvania, public protests emphasising claims that the government was capitulating to Hungarian interests received a much better turnout. Tudor overtook Iliescu in the popularity stakes arid the PRM jumped to $11 \%$ in the opinion polls nearly three times what it had received in the 1996 election $^{51}$.

It had been widely assumed that the association of the nationalist bloc with dubious financial projects (the Caritas pyramid scheme and the failed Dacia Felix bank) and its rampant careerism, had marginalised the chauvinists parties for a considerable period $^{52}$. But a lot of discontented voters seemed prepared to forgive the nationalists their sins, especially since there was no other part of the opposition able to articulate their complaints about the government.

More worrying was the tendency of mainstream newspapers to adopt an increasingly anti-Hungarian stance. NaŢional, a new Bucharest daily launched in the summer of 1997 by Ion Cristoiu the doyen of Romanian tabloid journalism, compared the Ciorbea government's concessions to Hungarians with the ones made by the communists in their early years of power ${ }^{33}$. Adevârul, the chief newspaper of record in Romania, was particularly strident. Its editorial of 21 October 1997, coinciding with a visit to Romania by the Hungarian Premier, accused the government of making numerous concessions to Hungarian interests without receiving a single thing in return. A battle for circulation in times of falling purchasing power among readers partly explains why the mainstream press is ready to flirt with chauvinism. The longstanding tendency for 
Romanian opinion formers to seek a foreign excuse for domestic misfortunes may also shed light on press behaviour at this time.

Gyorgy Frunda, the UDMR presidential candidate in the 1996 elections, had warned early in 1997 that « if things go wrong [for the government], it is the Hungarians who are going to be blamed $\aleph^{54}$. The Ciorbea government declined to mount an energetic defence of its minority policies or refute nationalist claims that it was retreating in the face of unacceptable Hungarian demands. This lethargy contrasted with the promise which both the Romanian and Hungarian Presidents had made in Cluj on 27 May 1997 when they said that «we will not allow any extremist minorities in Romania or Hungary to speak on behalf of our people $»^{55}$. That promise was easier to fulfil in Hungary where the right-wing opposition has reluctantly thrown, its support behind the détente with Romania, realising how popular it is with Hungarian voters. But in Romania the attempt to integrate the Hungarian minority into the Romanian body politic by removing many of its grievances has so far found few eloquent defenders; the government was even afraid to move against Mayor Funar in Cluj after he was deposed in March as leader of his own party. The provocative actions which had been his trademark in the Iliescu years continued unimpeded. The Cluj prefect (a Bucharest appointee) said in October 1997 that the system of justice and local administration, remained in the hands of cluj nationalists ${ }^{56}$. This was a tacit admission that the government simply lacked the authority to bring the mayor to heal.

Inter-ethnic tensions have also surfaced within the Ciorbea government (along with many other types as its own belief in its abilities to carry through radical reforms has declined). In July 1997, a majority of Senators from Ciorbea's party, the Partidul NaŢional Ţărănesc-Creştin, Democrat Christian Democrats (National Peasant and Christian Democratic Party, PNTCD), opposed the modification of the 1995 education law which would have allowed the subjects of history and geography to be taught in Hungarian in state schools in minority areas ${ }^{57}$. The UDMR, in its turn, threatened to withdraw from the government unless it pushed through the educational law revision by emergency ordinance ${ }^{58}$. This would avoid the need for a parliamentary vote which the government might have lost because of the opposition of PNTCD members. The UDMR demand was met but it led to ill-feeling with its coalition partners.

Internal party politics can explain why such rigid positions are adopted. Many PNTCD senators opposed to Hungarian claims fear the loss of their seats to ultra-nationalists or else look for ways of advancing their claims inside a party whose leadership is dominated by aged survivors of Romanian prison camps. Similarly, in advance of the UDMR's fifth congress held in October 1997, the party's moderate leadership needed to show resolution on the education question in order to isolate radicals around Bishop Laszlo Tokes who think the party has sold its parliamentary votes too cheaply. But the demands of party politics can have an unsettling affect on public opinion where sensitive ethnic questions are concerned. At least a clear majority in the UDMR is aware that no future government is likely to be so favourable to Hungarian interests as the Ciorbea one, however disappointing its legislative record. The UDMR congress avoided inflammatory statements or motions and it went largely unnoticed in the Romanian press which only tends to give detailed attention to the UDMR when it behaves in ways that are seen to correspond to certain negative stereotypes. 


\section{Conclusion}

59 The impetus for the 1996 bilateral treaty came from the West, in particular from the USA. Following the 1995 Dayton Agreement the USA saw the need to persevere with confidence-building strategies in South-Eastern Europe where, hitherto, it had been wary of deep involvements. When NATO invited former Warsaw Pact states to apply for membership, the Iliescu regime found that the rewards for burying its quarrel with Hungary, in terms of collective security and greater integration with western institutions, outweighed any domestic benefits to be obtained from manipulating an ancient rivalry for electoral purposes.

The Iliescu regime's residual authoritarianism, nationalist character, and reliance on office-holders whose influence can be traced back to the pre-1989 hardline communist era, meant that it displayed certain neo-communist mentalities. But unlike states like Serbia or Belarus, still dominated by former high-ranking communists disdainful of democracy, Romania has shown enthusiasm for sheltering under a western security umbrella. The policy was, and is, hugely popular with an electorate deeply suspicious of Russia and disenchanted by the economic failures of the Iliescu regime.

Iliescu may also have felt that it would still be possible for Romania to ignore onerous conditions of NATO membership, such as the commitment to building democracy, just as Portugal, Turkey and Spain, had previously done. His opportunistic approach to reconciliation with Hungary and the state's Hungarian minority was shown during the 1996 election campaign when he exploited chauvinist sentiments in a failed bid to get re-elected. The new regime, shaped by the alliance of President Constantinescu and Premier Victor Ciorbea is undoubtedly more genuine in its willingness to honour the 1996 treaty and turn it into a platform for meaningful reconciliation. This was a totally new departure as Frunda, the ethnic Hungarian leader, noted : « from 1918 till now no leading figure in Romanian politics ever had the courage to say "let us normalise relations with Hungary $" 1{ }^{59}$.

But under pro-western reformers, the pace of reconciliation is still determined by the degree to which it will help Romania to break out of its isolation and become a part of mainstream Europe. Reconciliation with a historic rival still remains a means to a different end rather than being an overriding goal in itself. This was shown in the summer and autumn of 1997 when Romania's bids to be included in negotiations for the enlargement of both NATO and the EU were rejected. Scepticism about the ability to preserve good links with Hungary grew and enthusiasm for building bridges with the Hungarian minority diminished. Old disputes concerning the rights of the Hungarian minority quickly resurfaced and it was not just nationalists on the Romanian side who were ready to make difficulties.

63 If Romania and Hungary find themselves on different sides of a new security line cordoning off the Balkans from the rest of Europe, it will not be easy to preserve the much-vaunted security partnership that ministers from both countries have claimed now exists. Neither will Romania's efforts to pass from the communist and postcommunist era (1946-1996) to a liberal democratic one be easily accomplished if it finds itself out or, a limb in an uncertain security environment.

Romanian-Hungarian relations at inter-state and inter-communal level are still at the mercy of shifting events. But at least ethnic tensions on the ground shows little sign of 
resurfacing. A poll carried out in Romania in August 1997 found that only $5 \%$ of respondents answered yes to the question, « is there likely to be inter-ethnic conflict in your locality in the near future? $»^{60}$.

But it remains true that majorities are less inclined to make concessions to minorities when their own economic prospects are bleak. In hard times, demagogues who insist that minority rights are a violation of national sovereignty will always find a more receptive audience than in times of economic contentment. Romania after 1996 offers a fascinating example of a society facing massive economic hardships whose government is seeking simultaneously to address minority concerns. This is a very delicate balancing-act and it is not clear at the time of writing whether ruling reformers will be able to combine austerity policies and liberal minority ones without paying a high political price.

\section{NOTES}

1. Radio Bucharest, 26 September 1995, quoted by Szabo (Matyas), «"Historic Reconciliation" Awakens Old Disputes ", Transition, 2 (5), 08/03/96, p. 47.

2. The best recent account of the Transylvanian question is Nouzille (Jean), Transilvania, Zona De Contacte Si Conflicte, Bucharest: Editura Enciclopedica, 1995 (it was originally published in Strasbourg by Revue d'Europe Centrale in 1993 under the title La Transylvanie. Terre de contacts et de conflicts).

3. Dunay (Pal), « Hungary : defining the boundary of security », in Cowan Karp (Regina), Central and Eastern Europe: The Challenge of Transition, Oxford: Sipri / Oxford University Press, 1993, p. 135.

4. Oltay (Edith), «Minority Rights Still an Issue in Hungarian-Romanian Relations », RFE-RL Research Report, 1 (12), 20/03/92, pp. 17-18.

5. For statistics on the Hungarian minority, see Brunner (Georg), Nationality Problems and Minority Conflicts in Eastern Europe, Gutersloh : Bertelsmann, 1996, p.166.

6. Ambassador Alfred Moses's statemcnt was given extensive coveragein the Bucharest daily, Adevârul, of 26/02/96.

7. Mather (lan), « Seeking Stability in Europe », The European, 10/02/95.

8. Rompres, Romanian state news agency, 29/04/96.

9. In an effort to prepare the Romanian military for NATO entry, professional competence has been given higher priority than other branches of the state; in 1995 hardline nationalists were removed from key position and civilian control of the military has been strengthened.

10. Monitorul, 18/07/96 (http://www.nordest.ro/).

11. Fisher (Sharon), OMRI Daily Digest, 2 (150), 05/08/96.

12. Telegrama, Romanian daily news service, $22 / 07 / 96$. (http://www.infocom@fsc.eunet.ro/)

13. Hungarian radio, 12/05/96, quoted by BBC Survey of World Broadcasts, Eastern Europe, 14/05/96, $\mathrm{B} / 7$.

14. Telegrama, $12 / 08 / 96$.

15. Evenimentul Zilei, 19/08/96 (http:://www.express.ro/).

16. Telegrama Daily News Service, 18/03/96. 
17. Schöpflin (George), "The Quiet National Question», Warreport, (29), October-November 1994, p. 16.

18. Dunay (Pal), art.cit, p. 136.

19. Sammut (Dennis), Ethnic Problems Between the Romanian and Hungarian Communities in Romania, London: The Verification Technology Information Centre (VERTIC), 1994, p. 20.

20. Oltay (Edith), « Minorities as Stumbling Block in Relations with Neighbors », RFE-RL Research Report, 1 (19), 08/05/92, p. 28.

21. See Gallagher (Tom), Romania After CeauKescu: The Politics of Intolerance, Edinburgh: Edinburgh University Press, 1996, chapter 6.

22. Ibid., p. 75.

23. See Gallagher (Tom), "Nationalism and the Romanian Opposition », Transition, 2 (1), 12/01/96, pp. 30-32.

24. A defence of Iliescu's position is provided by Watts (Larry L.), «Ethnic Tensions: How the West Can Help », World Policy Journal, 12, (1), Spring 1995.

25. Stan (Valentin), «Nationalism and European Integration: Romania's Euro-Atlantic Integration ", International Studies, (1), 1995, pp. 41-43. By the summer of 1996 only the PUNR remained in alliance with Iliescu's party.

26. For the improvements in inter-ethnic relations in Tirgu Mureș, see Reed (John), « Mending Fences ", The Wall Street Journal, 30/06/97.

27. Andreescu (Gabriel), Weber (Renate), Evolutions in the D.A.H.R. conception on Hungarian minority rights, Bucharest : Centre For Human Rights, 1995, p. 44.

28. The UDMR adopted the concept of territorial autonomy on 27 May 1995 at its congress in the city of Cluj. See Gallagher (Tom), « Controversy in Cluj », Transition, 1 (15), 25/08/95, p. 59.

29. Oltay (Edith), « Minority Rights... », art.cit., p. 20.

30. Andreescu (Gabriel), Weber (Renate), op cit., p. 2.

31. Quoted in Cornea (Andrei), "Separatia "pasnica" sau hermeneutica fara control », 22, $10 / 07 / 96$.

32. Szabo (Matyas), art.cit., p. 49.

33. For an analysis of the election and its importance, see Popescu (Liliana), «A change of Power in Romania: The Results and Significance of the November 1996 elections ", Government and Opposition, 32 (2), Spring 1997.

34. On 9 November 1996 Iliescu tried to rally voters in Transylvania by warning in lurid terms of the dangers posed by the UDMR to Romanian national security, but the borrowinq of extremist rhetoric failed to rescue his sinking re-election campaign; indeed, the scale of his defeat was bigger in Transylvania than anywhere else in the country and it is clear that many Romanian nationalists voted for his opponent. See Evenimantul Zilei, 13/11/96.

35. Constantinescu (Emil), Le Monde, 22/02/97.

36. $22,7-13 / 01 / 97$.

37. Monitorul, 12/03/97.

38. România liberă, 28/05/97.

39. Monitorul, 14/03/97.

40. Rompres, Romanian state news service, $21 / 08 / 92$.

41. Monitorul, 12/03/97.

42. Monitorul, 13-14/03/97.

43. Evenimentul Zilei, 22/10/97. Babes-Bolyai university was now described by Ciorbea as «a multinational university " whose status could not be altered.

44. In opinion polls conducted up until October 1997, the CDR was regularly receiving $10-15 \%$ more support than the $30,17 \%$ of the vote it had received in 1996.

45. Evenimentul Zilei, 02/06/97. 
46. The poll was carried out by the Romanian Institute for Public Opinion Surveys (IRSOP) and detail were carried in Evenimentul Zilei, 14/06/97.

47. Monitorul, 12/07/97.

48. Ziua, 26/07/97.

49. Adevârul, 21/10/97.

50. Evenimentul Zilei, 23/06/97.

51. Reuters report, 22/09/97, published by Central European Online (Prague), 22/09/97 (http:// www.centraleurope.com/).

52. Gyorgy Frunda, the prominent UDMR politician even predicted in early 1997 that the biggest of the nationalist parties, Funar's PUNR would disappear from parliament in the next election. See Stefoi (Elena), Drept Minoritar, Spaime NaŢionale, Bucharest : Editura Kriterion, 1997, p. 179.

53. NaŢional, 22/07/97.

54. Stefoi (Elena), op cit., p. 87.

55. România liberă, 27/05/97.

56. Telegrama Daily News Service, 09/10/97.

57. Monitorul, 26/06/97.

58. Telegrama Daily News Service, 17/10/97.

59. Stefoi (Elena), op.cit., p. 26.

60. The poll was conducted by the Bucharest-based Centre for Urban and Rural Sociology between 16 and 24 August 1997. The full breakdown of answers to the question was "yes certainly » $(2 \%)$; «Yes, possibly» $(3 \%) ;$ «No » $(67 \%)$; « Not relevant because there are no different ethnic qroups in my locality » $(23 \%)$; «Don't know» $(5 \%)$. The findings were carried by Monitorul, 03/09/97.

\section{ABSTRACTS}

The terrible nature of events in the former Yugoslavia have obscured a long-running quarrel between Romania and Hungary which strengthened the forces of radical nationalism in both countries. In many ways, the Romanian-Hungarian dispute is the paradigm case of an interethnic dispute in Eastern Europe.

Nonetheless, Romania and Hungary have signed a treaty of friendship which it is hoped will inaugurate a period of lasting stability between two historic rivals. The author analyses the changing conditions which have enabled two formerly intractable neighbours to put aside their quarrels and it examines the obstacles that need to be overcome before a process of reconciliation can hope to be consolidated. Romanian-Hungarian relations at inter-state and inter-communal level are still at the mercy of shifting events.

La nature terrible des événements dans l'ancienne Yougoslavie ont masqué une vieille querelle entre la Roumanie et la Hongrie qui a renforcé les forces nationalistes dans les deux pays. La dispute roumano-hongroise représente, sous de multiples formes, le paradigme des rivalités interthniques en Europe de l'Est.

Néanmoins, les deux pays ont signé un traité d'amitié, dont on espère qu'il inaugure une longue période de stabilité entre deux rivaux historiques. L'auteur analyse les changements de conditions qui ont permis à deux anciens voisins intraitables de mettre de côté leurs querelles. Il passe en revue les obstacles devant être surmontés avant qu'un processus de réconciliation 
puisse être consolidé. Les relations roumano-hongroises, interétatiques et intercommunautaires, n'en demeurent pas moins instables.

\section{AUTHOR}

\section{TOM GALLAGHER}

Tom Gallagher est professeur d'Ethnic Conflict and Peace à the Bardford University. 